Review

\title{
Vascularization Strategies in Bone Tissue Engineering $\S$
}

\author{
Filip Simunovic*(1) and Günter Finkenzeller
}

check for

updates

Citation: Simunovic, F.; Finkenzeller G. Vascularization Strategies in Bone Tissue Engineering. Cells 2021, 10, 1749. https://doi.org/10.3390/ cells10071749

Academic Editors: Björn Behr and Levkau Bodo

Received: 21 June 2021

Accepted: 6 July 2021

Published: 11 July 2021

Publisher's Note: MDPI stays neutral with regard to jurisdictional claims in published maps and institutional affiliations.

Copyright: (c) 2021 by the authors. Licensee MDPI, Basel, Switzerland. This article is an open access article distributed under the terms and conditions of the Creative Commons Attribution (CC BY) license (https:/ / creativecommons.org/licenses/by/ $4.0 /)$.
Freiburg University Medical Center, Department of Plastic and Hand Surgery, Faculty of Medicine, University of Freiburg, 79106 Freiburg, Germany

* Correspondence: filip.simunovic@uniklinik-freiburg.de

$\S$ This work is dedicated to our recently retired head of department, Prof. Dr. G. Björn Stark, who established tissue engineering research in Freiburg.

\begin{abstract}
Bone is a highly vascularized tissue, and its development, maturation, remodeling, and regeneration are dependent on a tight regulation of blood vessel supply. This condition also has to be taken into consideration in the context of the development of artificial tissue substitutes. In classic tissue engineering, bone-forming cells such as primary osteoblasts or mesenchymal stem cells are introduced into suitable scaffolds and implanted in order to treat critical-size bone defects. However, such tissue substitutes are initially avascular. Because of the occurrence of hypoxic conditions, especially in larger tissue substitutes, this leads to the death of the implanted cells. Therefore, it is necessary to devise vascularization strategies aiming at fast and efficient vascularization of implanted artificial tissues. In this review article, we present and discuss the current vascularization strategies in bone tissue engineering. These are based on the use of angiogenic growth factors, the co-implantation of blood vessel forming cells, the ex vivo microfabrication of blood vessels by means of bioprinting, and surgical methods for creating surgically transferable composite tissues.
\end{abstract}

Keywords: vascularization; tissue engineering; bioprinting; bone; mesenchymal stem cell; endothelial cell

\section{Introduction}

Bone can be divided into an external layer, named cortical bone, and an internal layer, referred to as cancellous bone. Cortical bone shows extreme mechanical stiffness with relatively low porosity [1,2]. In contrast, cancellous bone shows very high porosity and only about 10 percent of the mechanical stiffness of cortical bone. Within the cortical bone, osteons form functional units that have the so-called haversian canals in the center, which contain nerves and blood vessels $[3,4]$. These osteons with the associated haversian canals are not found in cancellous bone and are also not necessary for the blood vessel supply due to the high porosity of this bone compartment.

During embryonic development, bone can be formed in two different ways: enchondral ossification and intramembranous ossification [5]. Intramembranous ossification is typical for flat bones such as skull bone [6]. Here, osteoblastic precursor cells (mesenchymal stem cells) differentiate directly into osteoblasts, which then synthesize the corresponding bone matrix. The development of long bones, on the other hand, takes place via the process of enchondral ossification [7]. Here, mesenchymal stem cells initially differentiate into chondrocytes, which initially form a cartilaginous precursor of the bone. In the further course, the ingrowth of blood vessels into the cartilage causes its destruction. Invading mesenchymal stem cells then differentiate into osteoblasts and induce bone formation, as in intramembranous ossification. Vascularization is of crucial importance in both ossification processes as well as further bone formation and in bone remodeling processes. In this context, vascularization is not only necessary for the immigration of mesenchymal stem cells, but also, in particular, for the supply of the metabolically active bone tissue with oxygen and nutrients and removal of waste products. 
The vascular endothelial growth factor (VEGF) plays a decisive role in the initiation of vascularization. It is formed by hypertrophic chondrocytes and mesenchymal stem cells and, as a potent angiogenic growth factor, induces the sprouting of preexisting surrounding blood vessels into the bone tissue [8]. It can therefore be assumed that VEGF is the decisive factor for the coupling of angiogenesis and osteogenesis. In mouse experiments, it could be shown that the inhibition of the VEGF function has a negative effect on bone angiogenesis and, thus, a negative effect on bone formation [9].

When a bone is fractured and blood vessels are damaged, hematoma forms and inflammatory cells migrate into the fracture site. The ingrowth of new blood vessels is essential for the formation of a soft callus consisting of fibroblasts and chondrocytes. The soft callus is, by way of enchondral ossification, converted into a rigid, calcified hard callus. Further mineralization and remodeling processes within the callus eventually lead to the repair of the damaged bone [10]. Here, too, it could be shown that VEGF plays an important role. For example, in a rabbit model, the application of recombinant VEGF to the fracture area led to an improvement in neovascularization and bone healing [11]. In contrast, the inhibition of VEGF in a mouse model resulted in decreased angiogenesis, decreased callus mineralization, and an inhibition of bone healing [12].

Due to the great importance of vascularization in both bone formation and in bone healing, it is clear that this aspect must also be taken into account in the tissue engineering of bone tissue (BTE). In the clinical context, bone defects can be treated with autologous or allogeneic bone grafts, with autologous bone replacement being the gold standard. Criticalsize bone defects can be caused by trauma, tumor, osteomyelitis, avascular bone loss, and non-union fracture, and are thus very common. Bone transplantation is performed in an estimated 2.2 million procedures yearly worldwide [13]. Smaller defects are bridged by non-vascularized bone grafts (e.g., iliac crest), while larger defects require pedicled or free tissue transfer $[14,15]$. However, the use of autologous bones is restricted due to the limited availability and due to the fact that an additional bone defect is created. In the case of allogeneic bone transplantation, additional limitations include possible rejection by the host and the possibility of disease transmission [16,17].

This review aims to provide an overview of the current vascularization strategies in the field of BTE. The various strategies discussed in this review article are summarized in Table 1.

Table 1. Advantages and disadvantages of the various vascularization strategies.

\begin{tabular}{|c|c|c|}
\hline $\begin{array}{c}\text { Vascularization } \\
\text { Strategy }\end{array}$ & Advantages & Disadvantages \\
\hline \multirow{3}{*}{$\begin{array}{l}\text { Angiogenic growth } \\
\text { factors }\end{array}$} & technically simple & optimization of drug-release system is necessary \\
\hline & numerous angiogenic growth factors are commercially available & $\begin{array}{l}\text { time delay between implantation and achieving } \\
\text { sufficient blood supply of implant }\end{array}$ \\
\hline & combination of angiogenic and osteogenic growth factors is possible & short half-life of some angiogenic growth factors \\
\hline \multirow{2}{*}{ Cell-based strategies } & $\begin{array}{c}\text { prevascularization of vessel networks in the implant is possible by } \\
\text { seeding endothelial cells }\end{array}$ & limited survival of implanted cells \\
\hline & combination of endothelial cells and bone-forming cells is feasible & $\begin{array}{l}\text { in a prospective clinical setting, autologous cells } \\
\text { have to be used }\end{array}$ \\
\hline \multirow{4}{*}{$\begin{array}{l}\text { Biofabrication of } \\
\text { vessel networks }\end{array}$} & $\begin{array}{l}\text { precise control of the spatial distribution of cells } \\
\end{array}$ & \multirow{2}{*}{ limited survival of implanted cells } \\
\hline & combined printing of cells and drug release hydrogels is feasible & \\
\hline & $\begin{array}{l}\text { combined printing of endothelial cells and bone-forming cells } \\
\text { is feasible }\end{array}$ & \multirow{2}{*}{$\begin{array}{l}\text { in a prospective clinical setting, autologous cells } \\
\text { have to be used }\end{array}$} \\
\hline & $\begin{array}{c}\text { acceleration of vessel formation by spatial alignment of } \\
\text { endothelial cells }\end{array}$ & \\
\hline \multirow{3}{*}{ Surgical strategies } & immediate blood supply can be achieved & technically challenging \\
\hline & $\begin{array}{c}\text { combination of immediate vascularization and naturally occurring } \\
\text { vascular sprouting in the AV-loop model }\end{array}$ & \multirow{2}{*}{$\begin{array}{l}\text { two stage approach is necessary to create a } \\
\text { vascularized implant }\end{array}$} \\
\hline & $\begin{array}{l}\text { integration of growth factors and cells is feasible in the } \\
\text { AV-loop model }\end{array}$ & \\
\hline
\end{tabular}




\section{Induction of Vascularization by Angiogenic Growth Factors}

Angiogenesis represents a mechanism by which new blood vessels are formed from a preexisting vascular network. In contrast, vasculogenesis means that new blood vessels are formed de novo by endothelial progenitor cells. During embryogenesis, these cells differentiate to mature endothelial cells and form a primitive vascular plexus that further matures into a hierarchical network with vessels of different calibers [18]. Under physiological as well as under pathophysiological conditions such as the growth of solid tumors, angiogenesis is initiated by the expression and secretion of pro-angiogenic diffusible soluble growth factors (GFs). Numerous pro-angiogenic growth factors have been identified in recent decades [19]. Prominent representatives are members of the vascular endothelial growth factor (VEGF) family [20], fibroblast growth factor (FGF) [21,22], angiopoietins (Ang) [23], transforming growth factor (TGF) [24,25], platelet-derived growth factor (PDGF) [26,27], and some interleukins [28,29]. Under normal conditions, the vasculature in the adult human body is relatively quiescent. However, during wound repair as well as in the context of solid tumor growth, angiogenesis in the respective tissues is dramatically stimulated. Angiogenic growth factors are expressed and secreted by a great variety of different cell types in response to different stimuli. Expression of VEGF, for example, can be induced by other GFs [30], activated oncogenes [31,32], and tissue hypoxia [33]. After secretion of the angiogenic GFs, they bind to their respective receptors on the cell surface of endothelial cells in neighboring blood vessels and induce several characteristic angiogenic cell responses. In order to trigger angiogenesis from neighboring vessels, the extracellular matrix and basement membrane of the blood vessel have to be degraded. This is achieved by inducing the expression of matrix metalloproteinases in endothelial cells. In addition, angiogenic GFs also induce the migration, invasion, and proliferation of endothelial cells, finally leading to the formation of a new lumen-containing blood vessel capillary, which matures by recruitment of vessel stabilizing mural cells such as pericytes or smooth muscle cells [34].

In order to induce in vivo neovascularization in tissue engineering applications, angiogenic GFs were mixed in hydrogels or coated on solid scaffolds that served as drug-release systems upon implantation. For example, Minardi and colleagues used multiscale microspheres, composed by a nanostructured silicon multistage vector (MSV) core and a poly(dl-lactide-co-glycolide) acid (PLGA) shell for controlled release of the angiogenic factor PDGF-BB [35]. The release kinetics of PDGF-BB was sustained over two weeks and a robust neovascularization was induced upon subcutaneous implantation in mice. Similarly, a VEGF release system was established by Chen and colleagues [36]. In this system, heparin cross-linked demineralized bone matrices were loaded with VEGF. This scaffold also showed sustained release of the angiogenic GF and induced angiogenesis in a subcutaneous implantation model. Angiogenic GFs were also used to induce vascularization in criticalsized bone defects. For example, Quinlan and colleagues incorporated VEGF in alginate microparticles [37]. These particles were then incorporated in collagen-hydroxyapatite scaffolds and implanted in a rat calvarial defect model. In these experiments, VEGF showed a sustained release rate and improved vascularization as well as bone formation in bone defects. The importance of VEGF in bone tissue engineering and bone regeneration and its central role in the coupling of angiogenesis and osteogenesis is highlighted by several recent review articles [38-40].

A great variety of natural [41-43], semi-synthetic [44,45], and synthetic [46-49] hydrogels have been used during the past decade for the release of a great variety of different GFs in order to improve neovascularization in BTE. From these studies, it became clear that an effective angiogenic therapy is strictly dependent not only on the right GF or the right combination of different GFs, but also on a temporal and dose controlled release of the angiogenic GFs. In the case of VEGF, for example, it was shown that a high initial burst of release, leading to an unphysiologically high concentration of VEGF in the implanted construct and the surrounding tissue, is associated with the appearance of functionally impaired blood vessels. In this case, the high concentration of VEGF leads to the formation 
of immature leaky blood vessels, whereas lower doses of VEGF induced the formation of mature functional blood vessels within the implanted construct [50].

As further development of the vascularization strategy on the basis of single recombinant angiogenic GFs, release systems were developed in which two or more GFs are released. For example, two angiogenic GFs, VEGF, and PDGF-BB were used with the aim to induce the formation of blood vessels with increased inherent stability and maturity [45,51]. Angiogenic GFs have also often been combined with osteogenic factors in order to enhance bone tissue formation in BTE applications. For example, Suárez-González and colleagues have loaded porous beta tricalcium phosphate ( $\beta$-TCP) scaffolds with VEGF and a biologically active peptide derived from human bone morphogenetic protein (BMP)-2 [52]. They were able to show a controlled sequential delivery of both factors over a time course of 60 days. Moreover, by using a sheep intramuscular implantation model, in vivo biological activity of both factors was demonstrated. Similarly, Kuttappan and colleagues combined BMP-2 with VEGF or bFGF and were able to show increased vascularization and bone formation in a rat critical sized calvarial defect model [53].

Although many studies have shown significant benefits of angiogenic GF delivery, therapeutic effects are sometimes hampered by the short half-life of recombinant GFs and, as above-mentioned, by problems in achieving the correct spatial and temporal release kinetics. In summary, an effective and safe angiogenic therapy based on recombinant GFs is not only dependent on the right combination of GFs delivered, but also on a temporal and dose controlled release.

Therefore, alternative delivery strategies have been developed based on the gene modification of cells that are implanted into scaffolds for BTE. In many cases, osteogenic cells such as primary osteoblasts or mesenchymal stem cells (MSCs) were embedded in hydrogels and used for seeding solid scaffolds for implantation in bone defects. These cells can be genetically modified ex vivo with genes encoding angiogenic GFs before implantation. This results in transient or stable expression of the respective factors, depending on the method that is used to deliver the recombinant DNA into the cells. For example, Peng and colleagues genetically engineered muscle-derived stem cells to overexpress BMP-4 and VEGF [54]. By using a mouse calvarial bone defect model, they were able to show that BMP-4 and VEGF act synergistically to support bone healing. Similarly, Lee et al. transfected adipose tissue-derived stem cells (ASCs) with BMP-2 or VEGF encoding plasmids ex vivo [55]. By mixing the respective transfected ASCs in a ratio of 9:1 (BMP-2-transfected versus VEGF-transfected ASCs), they were able to show optimal effects on angiogenesis, osteogenesis, and bone healing after implantation of the cell mixture into a calvarial defect model. FGF was also used successfully in an ex vivo gene therapeutic approach to support bone healing [56]. In this case, FGF-2 was transfected into bone marrow-derived MSCs (BMSCs) before implantation in a rat calvarial defect. The authors were able to demonstrate increased vasculogenesis as well as improved bone healing in this defect model.

\section{Cell-Based Strategies for Vascularization}

Osteogenesis and vasculogenesis are key processes in the generation of bone tissue, and it is well established that they share common signaling pathways [57-59]. Therefore, co-culturing vascular and osteogenic lineage cells have become a cornerstone in BTE. Liu et al. were able to identify 259 publications on co-culture systems in tissue engineering, 85 of which focused on bone tissue [60]. This chapter focuses on cell types used for co-culture experiments, experimental models, and modes of communication between osteogenic and vasculogenic components.

\subsection{Cell Types Used in Co-Culture Systems}

Cells of various sources, differentiation stages, and from various species have been successfully used to support bone regeneration. Osteogenic cells can be categorized in mature primary osteoblast cultures, osteogenic precursors, cell lines, and bone marrow aspirates. Human osteoblast (hOB) primary cultures are widely employed and can be 
gained (e.g., from the femora of patients during hip arthroplasty). These cells are robust but they tend to proliferate slowly and cannot be expanded for more than several passages. The advantages are that they are a relevant clinical model, are able to produce mineralized bone matrix immediately upon implantation, and are able to induce angiogenesis. However, reproducing results with hOBs can prove challenging since patients are heterogeneous and, even in one patient, the osteoblasts are not a homogenous population. More commonly, immortalized bone cell lines are used because of ease of handling and better reproducibility of results [61]. However, these cell types have less clinical relevance and are not an adequate replacement for primary cultures, not least because immortalization changes the properties of the cells.

Bone marrow-derived osteoprogenitors were the first cell population to be used in BTE [62,63], but the quantity and quality of bone progenitors are highly variable. MSCs have multiple advantages and are under increased scrutiny for tissue engineering applications. MSCs are adult multipotent stem cells capable of differentiating in osteoblasts, chondrocytes, and adipocytes. MSCs have now been isolated from many sites throughout the body. They are primarily found in bone tissue, but since they are also present in adipose tissue, muscle, and the dental pulp, MSCs can be isolated with relative ease from the adult organism. The quality and the differentiation potential of MSCs vary and are subject to an increasing amount of research [64]. Based on the simplicity of isolation and their relatively high proliferation potential ex vivo, MSCs are very attractive for BTE application. However, upon implantation, it was recognized that these cells sometimes show limited survival and osteogenic potential, restricting their therapeutic value. In this context, it was shown that hypoxic preconditioning is beneficial for MSCs. Hypoxia induces Hif-1alpha-dependent expression of oxygen-sensitive genes such as VEGF and bFGF [65] and it can be assumed that this leads to improved angiogenesis upon implantation of preconditioned MSCs. Moreover, it was also shown that hypoxic preconditioning improves cell survival and osteogenic differentiation of MSCs, leading to improved bone healing in critical-sized bone defects upon implantation of preconditioned MSCs [66,67].

In BTE applications, the MSCs need to be directed toward osteogenic phenotype, most commonly through the addition of growth factors (see previous chapter) or through cultivation on bone-derived ECM, which is proven to have osteogenic (and vasculogenic) properties [68-75]. Alternative stem cell sources are embryonic stem cells and induced pluripotent stem cells [76].

Endothelial cells are a more heterogeneous family than osteoblasts. Endothelial cells (ECs) are different in arteries, veins, and capillaries, as are ECs from different organs, and ECs are found in micro- and macrocirculation. They differ with respect to morphology, density, permeability of the vessels, gene expression profile, hemostatic competence, and angiogenic potential [77]. The most commonly used ECs, due to ease of harvest and culturing, are human umbilical vein ECs (HUVECs). Since the vasculature required to perfuse the emerging bone construct is microvasculature, these are not the most physiological choice. However, harvesting microvascular ECs from bone or other organs is technically demanding, with the exception of dermal microvascular ECs. Endothelial progenitor cells (EPCs) are extracted from peripheral blood or umbilical cord blood. They have high proliferation potential and a higher capillary-forming potential compared to ECs [78]. Furthermore, they secrete osteogenic factors such as bone morphogenic protein family members, TGF-beta, and enhance osteogenesis [79].

\subsection{Modes of Communication}

Cells communicate through soluble molecules secreted in the extracellular space (paracrine signaling) by cell-to-cell contact (adherens junctions) or by direct cytoplasmic cell-to-cell transport of molecules through gap junctions. Signaling molecules can thus exert influence on both bone and vasculature forming cells if they are secreted by one of the partners. 
Growth factors can be stored in the extracellular matrix (ECM) and, upon regulated proteolysis by matrix-metalloproteases, presented to cells [80-82]. This method of growth factor storage is so efficient that it has been possible to isolate growth factors from archeological findings dating from the Neolithic [83]. Additionally, components of the ECM can exert influence by direct mechanical action on the cellular membrane, which is transmitted inside the cell by the cytoskeleton. For example, integrins can trigger tyrosin-kinase receptors by direct contact [84]. The importance of ECM is becoming increasingly recognized. ECM of fibroblasts [85], chondrocytes, and endothelial cells [70,86] was shown to induce osteogenesis, and the ECM of osteoblasts induced the formation of the capillaries [87]. These observations are highly relevant for tissue engineering applications, as it is possible to seed ECM on a scaffold and thus eliminate the need for one co-culture partner.

Another possible mode of cellular communication is the exchange of microRNA molecules. During the past decades, a number of miRNAs have been identified that regulate osteogenesis and vaculogenesis, and recently, there has been interest by our group and others in identifying key miRNAs that influence both processes. Based on experimental data and proposed targets, the following miRNAs have been presumed to play a role in osteogenic-angiogenic coupling: miR-9, miR-10a, miR-20a, miR-26a, miR-29b, miR-31, miR-34a, miR-92a, miR-125b, miR-126 [88-90], miR-135b, miR-181a, miR-195, miR200b, miR-210, miR-222, and miR-424 (see Frohlich et al. for an exhaustive review [91]). Identifying key miRNA players would be favorable as these can be effectively augmented or inhibited in in vitro and in vivo conditions.

\subsection{Co-Culture Models}

Under experimental conditions, cells can be co-cultivated with or without direct contact to each other. Furthermore, cell cultures can be 2- or 3-dimensional. A culture prohibiting cellular contact will investigate paracrine factors, and such experiments can be performed while separating cells by a membrane, or using conditioned medium or conditioned ECM. In performing co-culture experiments, the ratio of co-cultivation partners is important, as is the choice of medium, which needs to ensure viability and induce the desired functional development of both cell types. Cultivating cells separately will discard the need for separating cells and will provide a purer population for investigation. However, we and others have repeatedly observed that the strongest osteogenic and angiogenic effects are observed in direct contact $[57,88,92,93]$.

A direct co-culture allows multiple levels of interaction between cells and is a more physiologic model. However, it requires that the cells are separated before performing experiments, and this implies a possibility of the contamination of results by the co-cultivation partner. Thus, the efficacy of the separation method has to be reliably and repeatedly tested. Most studies have been performed in 2D cultures, but cells can also be co-cultured as spheroids or within a scaffold as 3D cultures. 3D cultures are closer to physiological conditions and they allow for the investigation of more complex cellular behavior (e.g., tube formation by ECs) $[57,59,94-97]$. 3D cultures on scaffolds are closer to the construct, which is to be implanted in the in vivo part of a study than a 2D culture [98-100].

As discussed in other parts of this review, bone tissue engineering is making remarkable strides and we are now able to produce constructs which, upon implantation, form perfused blood vessels and produce mineralized matrix [101]. However, knowledge of common osteogenic and angiogenic processes, types of partners and conditions of co-cultivation as well as modes of interaction between them, are prerequisites for such developments, and these can be gained only by systematic and standardized research under defined conditions.

\section{Induction of Vascularization by Biofabrication of Vessel Networks}

The classical BTE concept is based on scaffolds that are randomly seeded with boneforming cells and cells that provide the vasculature upon implantation, as already discussed 
in the previous sections. However, the prevascularization strategy that is based on the targeted fabrication of blood vessels employs the technique of 3D-bioprinting.

3D-bioprinting represents an additive manufacturing process for the production of artificial tissues that combines biomaterials, cells, and growth factors that are deposited in a layer-by-layer manner [102,103]. This technique allows precise control of the spatial distribution of cells within the bioprinted construct and opens the way to printing multiple cell types in a biomimetic manner to produce an artificial tissue that corresponds more closely to the native target tissue than would have been possible with classical tissue engineering.

\subsection{Bioprinting Methods}

Different printing methods have been adapted for the bioprinting of mammalian cells. These methods include inkjet printing (e.g., drop-on-demand, DoD), extrusion-based printing, and laser-assisted printing [104]. For bioprinting, cells are dispersed into hydrogels to form a so called bioink. The hydrogels need to exhibit high cytocompatibility, must be printable, and must provide a sufficient mechanical stability to the printed construct [105], where the integration of all these conditions is a major challenge in bioprinting.

Inkjet printing is a non-contact printing technique that could precisely deposit droplets of cell-laden bioinks. The diameter of the bioprinted droplets using cell-laden bioinks typically varies between 110 and $150 \mu \mathrm{m}$, depending on the cell concentration [106]. This technique has the advantage of high printing speed and high resolution, but is limited by the fact that only low-viscosity bioinks can be used for bioprinting. Extrusion-based bioprinting in contrast can use bioinks with a wide range of viscosities and represents a contact printing technique by which bioinks are extruded through a microscale nozzle. Due to its ease of control and cost-effectiveness, extrusion-based bioprinting is widely used, but is limited by a relatively low printing speed $[107,108]$. In contrast to extrusion-based bioprinting, laser-assisted bioprinting is relatively expensive, but is associated with a high printing resolution and a high post-printing cell survival [109].

The technology of bioprinting has already been used to print of blood vessels in 3D-tissue constructs and can be considered to represent a new kind of prevascularization strategy. There are two major routes of vascularization reported in the literature: the bioprinting of vessel-forming cells (endothelial cells) and the printing of sacrificial structures that can be removed, leaving behind a microchannel that can be populated by endothelial cells. Table 2 gives an overview of the vascularization strategies that are followed in bioprinting.

\subsection{Bioprinting of Endothelial Cells}

Endothelial cells are bioprinted in high density in suitable bioinks such as fibrin or collagen in the form of lines or branched structures in the form of native blood vessels. Upon in vitro culture of these bioprinted constructs, self-organization of endothelial cells and lumen formation can be detected. These endothelial structures resemble early blood vessel capillaries in such a way that lumina are confined by a single layer of endothelial cells.

Our group has bioprinted HUVECs in the form of high density suspension, or in the form of endothelial spheroids by drop-on-demand in fibrin hydrogels as bioink [100]. After three days of in vitro incubation, HUVECs formed a lumen-containing blood vessel with a single layer of CD31-positive endothelial cells. From this main vessel, smaller, undirected side branches were formed by sprouting cells, inducing a first step toward a simplistic hierarchically organized network. Exactly the same approach was used to print HUVECs by DoD inside a cuboid structure consisting of adipose tissue-derived MSCs that were printed by extrusion-based bioprinting. These constructs were implanted subcutaneously into SCID mice. Bioprinted HUVECs were able to form functional perfused blood vessels of different calibers in vivo. These human blood vessels were stabilized by mouse mural cells invading the artificial tissue. Moreover, in these experiments, bioprinted MSCs were able to synthesize a calcified bone matrix as an indicator of ectopic bone formation [101]. 
Table 2. Strategies for the bioprinting of blood vessels: bioprinting of cells and bioprinting of channels.

\begin{tabular}{|c|c|c|c|}
\hline Printing Method & Bioink/Sacrificial Ink & $\begin{array}{c}\text { Cell Type in Bioink/Cell Type Used } \\
\text { for Endothelialization of } \\
\text { Microchannels }\end{array}$ & References \\
\hline \multicolumn{4}{|c|}{ Bioprinting of cells } \\
\hline inkjet & fibrin & HUVECs & {$[100,101]$} \\
\hline inkjet & fibrin & HUVEC spheroids & [99] \\
\hline inkjet & agarose/collagen & HUVECs, human dermal fibroblasts & [110] \\
\hline extrusion & gelatin-based & $\begin{array}{l}\text { human dermal microvascular } \\
\text { endothelial cells }\end{array}$ & [111] \\
\hline extrusion & gelatin methacryloyl (GelMA) & HUVECs & {$[112,113]$} \\
\hline extrusion & $\begin{array}{c}\text { gelatin methacryloyl } \\
(\text { GelMA)/fibrin }\end{array}$ & HUVECs & [114] \\
\hline extrusion & gelatin methacryloyl (GelMA) & $\begin{array}{l}\text { human aortic endothelial cells } \\
\text { (HAECs), human aortic smooth } \\
\text { muscle cells }\end{array}$ & [115] \\
\hline extrusion & fibrin/polycaprolacton (PCL) & HUVECs & [116] \\
\hline extrusion & $\begin{array}{c}\text { gelatin methacryloyl } \\
\text { (GelMA)/hyaluronic acid } \\
\text { (HA)/glycerol/gelatin }\end{array}$ & $\begin{array}{l}\text { HUVECs, smooth muscle cells } \\
\text { (SMCs) }\end{array}$ & [117] \\
\hline extrusion & laponite/alginate/methylcellulose & HUVECs & [118] \\
\hline extrusion & $\begin{array}{c}\text { methacrylated hyaluronic } \\
\text { acid/methacrylated } \\
\text { gelatin/hyaluronic acid } \\
\end{array}$ & stromal vascular fraction (SVF) & [119] \\
\hline extrusion & collagen & $\begin{array}{c}\text { dermal fibroblasts (FBs)/human } \\
\text { endothelial colony-forming cells } \\
\text { (HECFCs)/placental pericytes (PCs) }\end{array}$ & [120] \\
\hline extrusion & alginate/PEG-fibrinogen & HUVECs & [121] \\
\hline extrusion & $\begin{array}{l}\text { catechol-functionalized gelatin } \\
\text { methacrylate (GelMA/C) }\end{array}$ & $\begin{array}{l}\text { HUVECs, human coronary artery } \\
\text { smooth muscle cells (HCASMCs) }\end{array}$ & [122] \\
\hline extrusion & $\begin{array}{c}\text { hyaluronic } \\
\text { acid/glycerol/gelatin/fibrin }\end{array}$ & HUVECs & [123] \\
\hline laser-assisted printing & collagen & endothelial progenitor cells (EPCs) & [124] \\
\hline laser-assisted printing & collagen & HUVECs & {$[125,126]$} \\
\hline \multicolumn{4}{|c|}{ Bioprinting of microchannels } \\
\hline inkjet & gelatin & HUVECs & [127] \\
\hline inkjet & alginate & without cells & [128] \\
\hline extrusion & gelatin & HUVECs & [129] \\
\hline extrusion & gelatin & without cells & [130] \\
\hline extrusion & gelatin & smooth muscle cells (SMC) & [131] \\
\hline extrusion & Pluronic F127 & $\begin{array}{l}\text { HUVECs, smooth muscle cells (SMC), } \\
\text { human dermal neonatal fibroblasts } \\
\text { (HDF) }\end{array}$ & [132] \\
\hline extrusion & Pluronic F127 & HUVECs & [133] \\
\hline extrusion & Pluronic F127 & without cells & [134] \\
\hline extrusion & polyvinylalcohol & without cells & [135] \\
\hline extrusion (coaxial) & alginat & without cells & [136] \\
\hline extrusion & agarose & HUVECs & {$[137,138]$} \\
\hline extrusion & carbohydrate glass & HUVECs & [139] \\
\hline extrusion & gelatin-sucrose & HUVECs & [140] \\
\hline stereolithography & hyaluronic acid & HUVECs & [141] \\
\hline
\end{tabular}

Similarly, Leucht and colleagues printed human dermal microvascular endothelial cells (HDMECs) and adipose tissue-derived MSCs in gelatin-based hydrogels by extrusion printing [111]. In this case, HDMECs were able to form vascular-like structures within 14 days of in vitro culture. Byambaa and colleagues also used extrusion-based bioprinting for the generation of vascularized structures [112]. In this case, HUVECs were printed in a gelatin methacryloyl (GelMA) hydrogel and were able to form capillary-like networks in vitro. Laser-assisted bioprinting was also used for printing ECs. Kérourédan et al. 
printed human endothelial progenitor cells (EPCs) along with MSCs between two collagen layers and observed the formation of a capillary-like vascular network, emerging from bioprinted EPCs [124]. The same group also used laser-assisted bioprinting for in situ printing of HUVECs. In this case, HUVECs were directly printed into critical-sized calvaria bone defects of mice, filled with MSC- and VEGF-loaded collagen. Bioprinted HUVECs were able to form organized microvascular networks on the collagen surface inside the bone defect, resulting in increased vascularization and bone regeneration rates after two months [125].

Extrusion-based bioprinting of HUVECs, along with MSCs in fibrin-hydrogels, was also used to print osteon-like patterns in vitro. In this case, the mechanical strength of the constructs was improved by additional printing of polycaprolacton (PCL), resulting in mechanical properties similar to native cortical bone. Upon subcutaneous implantation of the 3D-printed constructs, a significant increase in the number of blood vessels was detected in the 3D printed osteon-like scaffold [116].

HUVECs were also combined with other vascular cells such as smooth muscle cells (SMCs). For example, Xu and colleagues used extrusion-based bioprinting of HUVECs and SMCs in gelatin methacyloyl-based hydrogels (GelMA) with different concentrations of GelMA [117]. They produced a heterogeneous bilayer, composed of HUVECs-embedded in GelMA as an inner layer and SMC-loaded GelMA as an outer layer. The resulting heterogeneous bilayer construct closely resembled a native blood vessel.

\subsection{Bioprinting of Microchannels}

For the bioprinting of microchannels, sacrificial fugitive bioinks are used. These are printed in an environment of stable hydrogels containing the tissue forming cells. The sacrificial bioink is then removed by enzymatic, thermal, or mechanical methods or by incubation in cell culture medium, leaving behind hollow channels that can be populated by endothelial cells. The endothelial cells attach to the inner surface of the microchannels, thereby forming a uniform layer. In most cases, HUVECs are used as a source of endothelial cells. A classical sacrificial bioink that is often used is gelatin that can be printed by extrusion-based bioprinting at room temperature and can be liquefied by the incubation of the printed construct at $37^{\circ} \mathrm{C}[127,129,131,142]$. Examples of sacrificial bioinks that can be removed by enzymatic digestion are alginate and hyaluronic acid, which can be digested after printing by the incubation of the constructs in cell culture medium containing alginate lyase or hyaluronidase, respectively [128,141].

Another popular sacrificial bioink is Pluronic F127, a triblock copolymer that can be easily printed and removed under mild conditions [132,133]. For example, Kolesky and colleagues printed Pluronic F127 at room temperature in a surrounding of human dermal fibroblasts suspended in gelatin methacrylate(GelMA) that was photopolymerized by UV-light after printing [133]. After bioprinting, the constructs were cooled down to $4{ }^{\circ} \mathrm{C}$ to liquefy the printed Pluronic strands inside the construct and the Pluronic strands removed by the application of a vacuum, leaving behind open microchannels. Thereafter, HUVECs were injected into the microchannels where they formed a confluent monolayer within $48 \mathrm{~h}$ of incubation.

Although the goal of creating hollow microchannels is quite easy to achieve with the bioinks described above, numerous other bioinks have been described in this context. Other sacrificial bioinks that were used in the literature for the fabrication of hollow microchannels comprise polyvinylalcohol [135], gelatin-sucrose [140], carbohydrate glass [139], and agarose $[137,138]$.

\section{Surgical Strategies for Vascularization}

A major issue with all the above strategies is the time needed until the replaced tissue is vascularized by the host. Tissues are oxygenized by diffusion over a distance of $200 \mu \mathrm{m}$, meaning that cells in the middle of the construct will invariably undergo hypoxic cell death [143-145]. In order to create stable constructs that reliably integrate in 
the host tissue, it is paramount to deliver nutrients to these cells by neovascularization. Neovasculariation can take the form of angiogenesis, which describes a process in which host vessels proliferate and penetrate the construct, or vasculogenesis, which implies that vessels are developed in the implant. In order to avert hypoxic cell death, which occurs during the first days after implantation [146], surgical strategies have been devised in order to vascularize the implant immediately after implantation.

The "in vivo bioreactor" principle unites traditional reconstructive surgery techniques and tissue engineering by relying on the host body as a bioreactor [147]. Imaging data are used to calculate the form and size of the defect. Chambers are then created, which correspond to the defect, filled with the preferred construct (cells, scaffold, growth factors), and implanted at a defect-remote site in the body. After a period of prelamination, the flap containing the construct is transferred into the defect and the vascular pedicle of the flap containing the construct is microsurgically anastomosed to recipient vessels. In this way, immediate and complete perfusion of the construct is achieved $[143,148]$. This technique is well-established experimentally in large animals (pig and sheep) and has been successfully performed in humans. In 2004, a subtotal replacement mandible consisting of a titanium mesh cage filled with bone mineral blocks coated in bone morphogenic protein 7 and bone marrow aspirate containing undifferentiated precursors was grown inside the latissimus dorsi muscle of a patient with previous subtotal mandibulectomy due to neoplasm. The muscle-construct unit was microsurgically transferred to the recipient site after seven weeks, and it showed good integration and a favorable aesthetic and functional outcome [149]. This approach avoids raising bone donor tissue, but it necessitates raising a muscle flap, which also represents considerable donor site morbidity. Another drawback is the technical complexity, need for two major surgeries, and a treatment period of several months.

Alternatively, and in order to avoid the harvest of a flap, an arteriovenous (AV) loop can be created. This approach involves anastomosing an artery with a vein, and transferring this "neopedicle" to the construct chamber, where it has to undergo microvascular sprouting in order to infiltrate the construct [150]. This approach was extensively verified experimentally [151,152] in large animal models [153] and clinically [154]. This technique also requires considerable time for the engineered tissue to vascularize by sprouting, necessitating hospitalization of several months [155], and thus limiting its clinical use.

To accelerate vascularization in the AV-loop chamber, growth factors [156] and stem cells [157] have been incorporated in the construct with promising results. These data suggest that combining other vascularization strategies in an AV-loop concept is a promising avenue of further research.

\section{Conclusions and Future Directions}

Strategies to support vascularization play an important role in the tissue engineering of artificial tissues, especially bone tissue. In this review article, we focused on four different vascularization strategies. These are based on the use of angiogenic growth factors, the implantation of endothelial cells, microfabrication of blood vessels by means of bioprinting, and on microsurgical principles. Each of these strategies has its specific advantages and disadvantages. However, based on our literature review, it has become clear that (co)implantation of bone- and blood vessel-forming cells is currently the predominant strategy in in vivo bone healing models.

It is feasible that tissue engineering applications will increasingly enter clinical settings and commercial applications. A good example of a standardized protocol with large-scale potential is the production of scaffolds seeded by mesenchymal stem cells extracted from the host (www.epibone.com, accessed on 7 July 2021). The scaffolds are perfused in bioreactors that are tailored to the defect, based on computer tomography images [158].

Future developments will rely on improvements in one single strategy. Progress is to be sought in the combination of strategies. A thorough understanding of all the presented methods as well as the experimental and clinical aspects of the task at hand, is required to compensate for individual disadvantages of each strategy. Furthermore, access to novel 3D 
bioprinting technologies allows for the convergence of bioengineering, materials science, and cell biology at an unprecedented level. Specifically, it is now possible to create 3dimensional constructs containing functioning vessels, multiple cell types, a rigid external scaffold, and an internal hydrogel containing recombinant growth factors.

Author Contributions: G.F. and F.S. wrote the article. Both authors have read and agreed to the published version of the manuscript.

Funding: The authors did not receive external funding for this work.

Institutional Review Board Statement: Not applicable.

Informed Consent Statement: Not applicable.

Data Availability Statement: There is no supporting data pertinent to this article.

Acknowledgments: We would like to thank Stefan Zimmerman, Department of Microsystems Engineering, Freiburg University, for critically revising the article, and Calvin Früh for preparing the table.

Conflicts of Interest: The authors declare no conflict of interest.

\section{References}

1. Bala, Y.; Zebaze, R.; Seeman, E. Role of cortical bone in bone fragility. Curr. Opin. Rheumatol. 2015, 27, 406-413. [CrossRef] [PubMed]

2. Morgan, E.F.; Unnikrisnan, G.U.; Hussein, A.I. Bone Mechanical Properties in Healthy and Diseased States. Annu. Rev. Biomed. Eng. 2018, 20, 119-143. [CrossRef] [PubMed]

3. Ascenzi, M.G.; Roe, A.K. The osteon: The micromechanical unit of compact bone. Front Biosci. 2012, 17, 1551-1581. [CrossRef] [PubMed]

4. Chang, B.; Liu, X. Osteon: Structure, Turnover, and Regeneration. Tissue Eng. Part B Rev. 2021. [CrossRef] [PubMed]

5. Salhotra, A.; Shah, H.N.; Levi, B.; Longaker, M.T. Mechanisms of bone development and repair. Nat. Rev. Mol. Cell Biol. 2020, 21, 696-711. [CrossRef] [PubMed]

6. Percival, C.J.; Richtsmeier, J.T. Angiogenesis and intramembranous osteogenesis. Dev. Dyn. 2013, 242, 909-922. [CrossRef]

7. Berendsen, A.D.; Olsen, B.R. Bone development. Bone 2015, 80, 14-18. [CrossRef]

8. $\mathrm{Hu}, \mathrm{K} . ;$ Olsen, B.R. Osteoblast-derived VEGF regulates osteoblast differentiation and bone formation during bone repair. J. Clin. Investig. 2016, 126, 509-526. [CrossRef]

9. Gerber, H.P.; Vu, T.H.; Ryan, A.M.; Kowalski, J.; Werb, Z.; Ferrara, N. VEGF couples hypertrophic cartilage remodeling, ossifi-cation and angiogenesis during endochondral bone formation. Nat. Med. 1999, 5, 623-628. [CrossRef]

10. Stegen, S.; van Gastel, N.; Carmeliet, G. Bringing new life to damaged bone: The importance of angiogenesis in bone repair and regeneration. Bone 2015, 70, 19-27. [CrossRef]

11. Kleinheinz, J.; Stratmann, U.; Joos, U.; Wiesmann, H.-P. VEGF-Activated Angiogenesis During Bone Regeneration. J. Oral Maxillofac. Surg. 2005, 63, 1310-1316. [CrossRef]

12. Street, J.; Bao, M.; DeGuzman, L.; Bunting, S.; Peale, F.V., Jr.; Ferrara, N.; Steinmetz, H.; Hoeffel, J.; Cleland, J.L.; Daugherty, A.; et al. Vascular endothelial growth factor stimulates bone repair by promoting angiogenesis and bone turnover. Proc. Natl. Acad. Sci. USA 2002, 99, 9656-9661. [CrossRef]

13. Dimitriou, R.; Tsiridis, E.; Carr, I.; Simpson, H.; Giannoudis, P.V. The role of inhibitory molecules in fracture healing. Injury 2006, 37, S20-S29. [CrossRef]

14. Russe, O. [Experience and results in filling up of the substantia spongiosa in old fractures and pseudarthrosis of the scaphoid bone of the hand]. Wiederherstellungschirurgie und Traumatol. Reconstr. Surg. Traumatol. 1954, 2, 175-184.

15. Taylor, G.I.; Miller, G.D.; Ham, F.J. The free vascularized bone graft. A clinical extension of microvascular techniques. Plast Reconstr. Surg. 1975, 55, 533-544. [CrossRef] [PubMed]

16. Wang, W.; Yeung, K.W. Bone grafts and biomaterials substitutes for bone defect repair: A review. Bioact. Mater. 2017, 2, $224-247$. [CrossRef] [PubMed]

17. Kurien, T.; Pearson, R.G.; Scammell, B.E. Bone graft substitutes currently available in orthopaedic practice: The evidence for their use. Bone Joint J. 2013, 95, 583-597. [CrossRef] [PubMed]

18. Risau, W.; Flamme, I. Vasculogenesis. Ann. Rev. Cell Dev. Biol. 1995, 11, 73-91. [CrossRef] [PubMed]

19. Folkman, J. Angiogenesis in cancer, vascular, rheumatoid and other disease. Nat. Med. 1995, 1, 27-31. [CrossRef] [PubMed]

20. Ferrara, N.; Henzel, W.J. Pituitary follicular cells secrete a novel heparin-binding growth factor specific for vascular endothe-lial cells. Biochem. Biophys. Res. Commun. 1989, 161, 851-858. [CrossRef]

21. Maciag, T.; Mehlman, T.; Friesel, R.; Schreiber, A.B. Heparin binds endothelial cell growth factor, the principal endothelial cell mitogen in bovine brain. Science 1984, 225, 932-935. [CrossRef] 
22. Shing, Y.; Folkman, J.; Sullivan, R.; Butterfield, C.; Murray, J.; Klagsbrun, M.; Shing, Y.; Folkman, J.; Sullivan, R.; Butterfield, C.; et al. Heparin affinity: Purification of a tumor-derived capillary endothelial cell growth factor. Science 1984, 223, 1296-1299. [CrossRef] [PubMed]

23. Suri, C.; Jones, P.F.; Patan, S.; Bartunkova, S.; Maisonpierre, P.C.; Davis, S.; Sato, T.N.; Yancopoulos, G.D. Requisite role of angi-opoietin-1, a ligand for the TIE2 receptor, during embryonic angiogenesis. Cell 1996, 87, 1171-1180. [CrossRef]

24. Schreiber, A.B.; Winkler, M.E.; Derynck, R. Transforming growth factor-alpha: A more potent angiogenic mediator than epi-dermal growth factor. Science 1986, 232, 1250-1253. [CrossRef]

25. Madri, J.A.; Pratt, B.M.; Tucker, A.M. Phenotypic modulation of endothelial cells by transforming growth factor-beta depends upon the composition and organization of the extracellular matrix. J. Cell Biol. 1988, 106, 1375-1384. [CrossRef] [PubMed]

26. Smits, A.; Hermansson, M.; Nister, M.; Karnushina, I.; Heldin, C.-H.; Westermark, B.; Funa, K. Rat Brain Capillary Endothelial Cells Express Functional PDGF B-Type Receptors. Growth Factors 1989, 2, 1-8. [CrossRef]

27. Ambrus, J.L.; Ambrus, C.M.; Toumbis, C.; Forgach, P.; Karakousis, C.P.; Niswander, P.; Lane, W.; Ambrus, J.L.; Ambrus, C.M.; Toumbis, C.; et al. Studies on tumor induced angiogenesis. J. Med. 1991, 22, 355-369.

28. Mahadevan, V.; Hart, I.R.; Lewis, G.P. Factors influencing blood supply in wound granuloma quantitated by a new in vivo technique. Cancer Res. 1989, 49, 415-419.

29. Motro, B.; Itin, A.; Sachs, L.; Keshet, E. Pattern of interleukin 6 gene expression in vivo suggests a role for this cytokine in angi-ogenesis. Proc. Natl. Acad. Sci. USA 1990, 87, 3092-3096. [CrossRef]

30. Finkenzeller, G.; Sparacio, A.; Technau, A.; Marme, D.; Siemeister, G. Sp1 recognition sites in the proximal promoter of the hu-man vascular endothelial growth factor gene are essential for platelet-derived growth factor-induced gene expression. Oncogene 1997, 15, 669-676. [CrossRef]

31. Finkenzeller, G.; Weindel, K.; Zimmermann, W.; Westin, G.; Marme, D. Activated Neu/ErbB-2 induces expression of the vascu-lar endothelial growth factor gene by functional activation of the transcription factor Sp 1. Angiogenesis 2004, 7, 59-68. [CrossRef]

32. Grugel, S.; Finkenzeller, G.; Weindel, K.; Barleon, B.; Marmé, D. Both v-Ha-Ras and v-Raf Stimulate Expression of the Vascular Endothelial Growth Factor in NIH 3 T3 Cells. J. Biol. Chem. 1995, 270, 25915-25919. [CrossRef] [PubMed]

33. Shweiki, D.; Itin, A.; Soffer, D.; Keshet, E. Vascular endothelial growth factor induced by hypoxia may mediate hypox-ia-initiated angiogenesis. Nature 1992, 359, 843-845. [CrossRef] [PubMed]

34. Claesson-Welsh, L.; Welsh, M. VEGFA and tumour angiogenesis. J. Intern. Med. 2013, 273, 114-127. [CrossRef]

35. Minardi, S.; Pandolfi, L.; Taraballi, F.; Wang, X.; De Rosa, E.; Mills, Z.D.; Liu, X.; Ferrari, M.; Tasciotti, E. Enhancing Vasculariza-tion through the Controlled Release of Platelet-Derived Growth Factor-BB. ACS Appl Mater Interfaces 2017, 9, 14566-14575. [CrossRef] [PubMed]

36. Chen, L.; He, Z.; Chen, B.; Yang, M.; Zhao, Y.; Sun, W.; Xiao, Z.; Zhang, J.; Dai, J. Loading of VEGF to the heparin cross-linked demineralized bone matrix improves vascularization of the scaffold. J. Mater. Sci. Mater. Electron. 2010, 21, 309-317. [CrossRef]

37. Quinlan, E.; López-Noriega, A.; Thompson, E.M.; Hibbitts, A.; Cryan, S.A.; O’Brien, F.J. Controlled release of vascular endothe-lial growth factor from spray-dried alginate microparticles in collagen-hydroxyapatite scaffolds for promoting vascularization and bone repair. J. Tissue Eng. Regen Med. 2017, 11, 1097-1109. [CrossRef] [PubMed]

38. Diomede, F.; Marconi, G.D.; Fonticoli, L.; Pizzicanella, J.; Merciaro, I.; Bramanti, P.; Mazzon, E.; Trubiani, O. Functional Rela-tionship between Osteogenesis and Angiogenesis in Tissue Regeneration. Int. J. Mol. Sci. 2020, 21, 3242. [CrossRef]

39. Dreyer, C.H.; Kjaergaard, K.; Ding, M.; Qin, L. Vascular endothelial growth factor for in vivo bone formation: A systematic review. J. Orthop. Transl. 2020, 24, 46-57. [CrossRef] [PubMed]

40. Grosso, A.; Burger, M.G.; Lunger, A.; Schaefer, D.J.; Banfi, A.; Di Maggio, N. It Takes Two to Tango: Coupling of Angiogenesis and Osteogenesis for Bone Regeneration. Front. Bioeng. Biotechnol. 2017, 5, 68. [CrossRef]

41. Kelpke, S.S.; Zinn, K.R.; Rue, L.W.; Thompson, J.A. Site-specific delivery of acidic fibroblast growth factor stimulates angiogen-ic and osteogenic responses in vivo. J. Biomed. Mater. Res. A 2004, 71, 316-325. [CrossRef]

42. Knaack, S.; Lode, A.; Hoyer, B.; Gabrielyan, A.; Roeder, I.; Gelinsky, M.; Rösen-Wolff, A. Heparin modification of a biomimetic bone matrix for controlled release of VEGF. J. Biomed. Mater. Res. Part A 2013, 102, 3500-3511. [CrossRef]

43. Piard, C.; Luthcke, R.; Kamalitdinov, T.; Fisher, J. Sustained delivery of vascular endothelial growth factor from mesoporous calcium-deficient hydroxyapatite microparticles promotes in vitro angiogenesis and osteogenesis. J. Biomed. Mater. Res. Part A 2021, 109, 1080-1087. [CrossRef] [PubMed]

44. Lindhorst, D.; Tavassol, F.; Von See, C.; Schumann, P.; Laschke, M.W.; Harder, Y.; Bormann, K.-H.; Essig, H.; Kokemüller, H.; Kampmann, A.; et al. Effects of VEGF loading on scaffold-confined vascularization. J. Biomed. Mater. Res. Part A 2010, 95, 783-792. [CrossRef] [PubMed]

45. Farokhi, M.; Mottaghitalab, F.; Ai, J.; Shokrgozar, M.A. Sustained release of platelet-derived growth factor and vascular endothelial growth factor from silk/calcium phosphate/PLGA based nanocomposite scaffold. Int. J. Pharm. 2013, 454, 216-225. [CrossRef] [PubMed]

46. Adibfar, A.; Amoabediny, G.; Eslaminejad, M.B.; Mohamadi, J.; Bagheri, F.; Doulabi, B.Z. VEGF delivery by smart polymeric PNIPAM nanoparticles affects both osteogenic and angiogenic capacities of human bone marrow stem cells. Mater. Sci. Eng. C 2018, 93, 790-799. [CrossRef] 
47. Bakshi, R.; Hokugo, A.; Khalil, D.; Wang, L.; Shibuya, Y.; Zhou, S.; Zhang, Z.; Rezzadeh, K.; McClendon, M.; Stupp, S.I.; et al. A Chemotactic Functional Scaffold with VEGF-Releasing Peptide Amphiphiles Facilitates Bone Regeneration by BMP-2 in a Large-Scale Rodent Cranial Defect Model. Plast. Reconstr. Surg. 2021, 147, 386-397. [CrossRef]

48. Shah, N.J.; Hyder, M.N.; Quadir, M.A.; Courchesne, N.-M.D.; Seeherman, H.J.; Nevins, M.; Spector, M.; Hammond, P.T. Adaptive growth factor delivery from a polyelectrolyte coating promotes synergistic bone tissue repair and reconstruction. Proc. Natl. Acad. Sci. USA 2014, 111, 12847-12852. [CrossRef] [PubMed]

49. Lü, L.; Deegan, A.; Musa, F.; Xu, T.; Yang, Y. The effects of biomimetically conjugated VEGF on osteogenesis and angiogenesis of MSCs (human and rat) and HUVECs co-culture models. Colloids Surfaces B Biointerfaces 2018, 167, 550-559. [CrossRef]

50. Davies, N.; Dobner, S.; Bezuidenhout, D.; Schmidt, C.; Beck, M.; Zisch, A.H.; Zilla, P. The dosage dependence of VEGF stimula-tion on scaffold neovascularization. Biomaterials 2008, 29, 3531-3538. [CrossRef]

51. Richardson, T.P.; Peters, M.C.; Ennett, A.B.; Mooney, D. Polymeric system for dual growth factor delivery. Nat. Biotechnol. 2001, 19, 1029-1034. [CrossRef] [PubMed]

52. Suárez-González, D.; Lee, J.S.; Diggs, A.; Lu, Y.; Nemke, B.; Markel, M.; Hollister, S.J.; Murphy, W.L. Controlled Multiple Growth Factor Delivery from Bone Tissue Engineering Scaffolds via Designed Affinity. Tissue Eng. Part A 2014, 20, 2077-2087. [CrossRef]

53. Kuttappan, S.; Mathew, D.; Jo, J.-I.; Tanaka, R.; Menon, D.; Ishimoto, T.; Nakano, T.; Nair, S.V.; Nair, M.B.; Tabata, Y. Dual release of growth factor from nanocomposite fibrous scaffold promotes vascularisation and bone regeneration in rat critical sized calvarial defect. Acta Biomater. 2018, 78, 36-47. [CrossRef] [PubMed]

54. Peng, H.; Wright, V.; Usas, A.; Gearhart, B.; Shen, H.C.; Cummins, J.; Huard, J. Synergistic enhancement of bone formation and healing by stem cell-expressed VEGF and bone morphogenetic protein-4. J. Clin. Investig. 2002, 110, 751-759. [CrossRef] [PubMed]

55. Lee, E.; Ko, J.Y.; Kim, J.; Park, J.W.; Lee, S.; Im, G.I. Osteogenesis and angiogenesis are simultaneously enhanced in BMP2/VEGF-transfected adipose stem cells through activation of the YAP/TAZ signaling pathway. Biomater. Sci. 2019, 7, 4588-4602. [CrossRef]

56. Qu, D.; Li, J.; Li, Y.; Gao, Y.; Zuo, Y.; Hsu, Y.; Hu, J. Angiogenesis and osteogenesis enhanced by bFGF ex vivo gene therapy for bone tissue engineering in reconstruction of calvarial defects. J. Biomed. Mater. Res. Part A 2011, 96, 543-551. [CrossRef]

57. Grellier, M.; Bordenave, L.; Amédée, J.; Grellier, M.; Bordenave, L.; Amédée, J. Cell-to-cell communication between osteogenic and endothelial lineages: Implications for tissue engineering. Trends Biotechnol. 2009, 27, 562-571. [CrossRef]

58. Das, A.; Botchwey, E. Evaluation of Angiogenesis and Osteogenesis. Tissue Eng. Part B Rev. 2011, 17, 403-414. [CrossRef]

59. Schott, N.G.; Friend, N.E.; Stegemann, J.P. Coupling Osteogenesis and Vasculogenesis in Engineered Orthopedic Tissues. Tissue Eng. Part B: Rev. 2021, 27, 199-214. [CrossRef]

60. Liu, Y.; Chan, J.K.Y.; Teoh, S.-H. Review of vascularised bone tissue-engineering strategies with a focus on co-culture systems. J. Tissue Eng. Regen. Med. 2012, 9, 85-105. [CrossRef]

61. Czekanska, E.M.; Stoddart, M.J.; Ralphs, J.R.; Richards, R.G.; Hayes, J.S. A phenotypic comparison of osteoblast cell lines versus human primary osteoblasts for biomaterials testing. J. Biomed. Mater. Res. Part A 2013, 102, 2636-2643. [CrossRef]

62. Grundel, R.E.; Chapman, M.W.; Yee, T.; Moore, D.C. Autogeneic bone marrow and porous biphasic calcium phosphate ce-ramic for segmental bone defects in the canine ulna. Clin. Orthop. Relat. Res. 1991, 266, 244-258.

63. Connolly, J.F.; Guse, R.; Tiedeman, J.; Dehne, R. Autologous marrow injection for delayed unions of the tibia: A preliminary report. J. Orthop. Trauma 1989, 3, 276-282. [CrossRef] [PubMed]

64. Colnot, C. Cell Sources for Bone Tissue Engineering: Insights from Basic Science. Tissue Eng. Part B Rev. 2011, 17, 449-457. [CrossRef] [PubMed]

65. Lambertini, E.; Penolazzi, L.; Angelozzi, M.; Bergamin, L.S.; Manferdini, C.; Sega, F.V.D.; Paolella, F.; Lisignoli, G.; Piva, R. Hypoxia Preconditioning of Human MSCs: A Direct Evidence of HIF-1 $\alpha$ and Collagen Type XV Correlation. Cell. Physiol. Biochem. 2018, 51, 2237-2249. [CrossRef] [PubMed]

66. Zhang, D.; Ren, L. Development Of Hypoxia-Inducible Factor 1alpha In Tissue Engineered Angiogen-Esis And Osteogenesis. Zhongguo Xiu Fu Chong Jian Wai Ke Za Zhi 2016, 30, 504-508. [PubMed]

67. Ho, S.S.; Hung, B.P.; Heyrani, N.; Lee, M.A.; Leach, J.K. Hypoxic Preconditioning of Mesenchymal Stem Cells with Subsequent Spheroid Formation Accelerates Repair of Segmental Bone Defects. Stem Cells 2018, 36, 1393-1403. [CrossRef] [PubMed]

68. Simunovic, F.; Steiner, D.; Pfeifer, D.; Stark, G.; Finkenzeller, G.; Lampert, F. Increased extracellular matrix and proangiogenic factor transcription in endothelial cells after cocultivation with primary human osteoblasts. J. Cell. Biochem. 2013, 114, 1584-1594. [CrossRef] [PubMed]

69. Simunovic, F.; Winninger, O.; Strassburg, S.; Koch, H.G.; Finkenzeller, G.; Stark, G.B.; Lampert, F.M. Increased differentiation and production of extracellular matrix components of primary human osteoblasts after cocultivation with endothelial cells: A quantitative proteomics approach. J. Cell. Biochem. 2019, 120, 396-404. [CrossRef] [PubMed]

70. Lampert, F.M.; Simunovic, F.; Finkenzeller, G.; Pfeifer, D.; Stark, G.B.; Winninger, O.; Steiner, D. Transcriptomic Changes in Os-teoblasts Following Endothelial Cell-Cocultivation Suggest a Role of Extracellular Matrix in Cellular Interaction. J. Cell Bio-Chem. 2016, 117, 1869-1879.

71. Thibault, R.A.; Mikos, A.G.; Kasper, F.K. Scaffold/Extracellular matrix hybrid constructs for bone-tissue engineering. Adv. Healthc. Mater. 2013, 2, 13-24. [CrossRef] [PubMed] 
72. Thibault, R.A.; Scott Baggett, L.; Mikos, A.G.; Kasper, F.K. Osteogenic differentiation of mesenchymal stem cells on pregenerated extracellular matrix scaffolds in the absence of osteogenic cell culture supplements. Tissue Eng. Part A 2010, 16, 431-440. [CrossRef]

73. Datta, N.; Pham, Q.P.; Sharma, U.; Sikavitsas, V.I.; Jansen, J.A.; Mikos, A.G. In vitro generated extracellular matrix and fluid shear stress synergistically enhance 3D osteoblastic differentiation. Proc. Natl. Acad. Sci. USA 2006, 103, 2488-2493. [CrossRef]

74. Kittaka, M.; Kajiya, M.; Shiba, H.; Takewaki, M.; Takeshita, K.; Khung, R.; Fujita, T.; Iwata, T.; Nguyen, T.Q.; Ouhara, K.; et al. Clumps of a mesenchymal stromal cell/extracellular matrix complex can be a novel tissue en-gineering therapy for bone regeneration. Cytotherapy 2015, 17, 860-873. [CrossRef] [PubMed]

75. Onishi, T.; Shimizu, T.; Akahane, M.; Omokawa, S.; Okuda, A.; Kira, T.; Nagak, Y.; Tanaka, Y. Osteogenic extracellular matrix sheet for bone tissue regeneration. eCM 2018, 36, 69-80. [CrossRef] [PubMed]

76. de Peppo, G.M.; Marcos-Campos, I.; Kahler, D.; Alsalman, D.; Shang, L.; Vunjak-Novakovic, G.; Marolt, D. Engineering bone tissue substitutes from human induced pluripotent stem cells. Proc. Natl. Acad. Sci. USA 2013, 110, 8680-8685. [CrossRef] [PubMed]

77. Hauser, S.; Jung, F.; Pietzsch, J. Human Endothelial Cell Models in Biomaterial Research. Trends Biotechnol. 2017, 35, 265-277. [CrossRef]

78. Ingram, D.A.; Mead, L.E.; Tanaka, H.; Meade, V.; Fenoglio, A.; Mortell, K.; Pollok, K.; Ferkowicz, M.J.; Gilley, D.; Yoder, M.C. Identification of a novel hierarchy of endothelial progenitor cells using human peripheral and umbilical cord blood. Blood 2004, 104, 2752-2760. [CrossRef]

79. Liu, Y.; Teoh, S.H.; Chong, M.S.; Lee, E.S.; Mattar, C.N.; Randhawa, N.S.K.; Zhang, Z.Y.; Medina, R.J.; Kamm, R.D.; Fisk, N.M.; et al. Vasculogenic and osteogenesis-enhancing potential of human umbilical cord blood endothelial colo-ny-forming cells. Stem Cells 2012, 30, 1911-1924. [CrossRef]

80. Paiva, K.B.S.; Granjeiro, J. Bone tissue remodeling and development: Focus on matrix metalloproteinase functions. Arch. Biochem. Biophys. 2014, 561, 74-87. [CrossRef] [PubMed]

81. Ricard-Blum, S.; Ballut, L. Matricryptins derived from collagens and proteoglycans. Front Biosci. 2011, 16, 674-697. [CrossRef]

82. Bix, G.; Iozzo, R. Matrix revolutions: 'tails' of basement-membrane components with angiostatic functions. Trends Cell Biol. 2005, 15, 52-60. [CrossRef]

83. Schmidt-Schultz, T.H.; Schultz, M. Intact growth factors are conserved in the extracellular matrix of ancient human bone and teeth: A storehouse for the study of human evolution in health and disease. Biol. Chem. 2005, 386, 767-776. [CrossRef]

84. Bianconi, D.; Unseld, M.; Prager, G.W. Integrins in the Spotlight of Cancer. Int. J. Mol. Sci. 2016, 17, 2037. [CrossRef]

85. Bae, S.E.; Bhang, S.H.; Kim, B.-S.; Park, K. Self-Assembled Extracellular Macromolecular Matrices and Their Different Osteogenic Potential with Preosteoblasts and Rat Bone Marrow Mesenchymal Stromal Cells. Biomacromolecules 2012, 13, 2811-2820. [CrossRef] [PubMed]

86. Kang, Y.; Kim, S.; Bishop, J.; Khademhosseini, A.; Yang, Y. The osteogenic differentiation of human bone marrow MSCs on HUVEC-derived ECM and beta-TCP scaffold. Biomaterials 2012, 33, 6998-7007. [CrossRef] [PubMed]

87. Palmieri, D.; Valli, M.; Viglio, S.; Ferrari, N.; Ledda, B.; Volta, C.; Manduca, P. Osteoblasts extracellular matrix induces vessel like structures through glycosylated collagen I. Exp. Cell Res. 2010, 316, 789-799. [CrossRef] [PubMed]

88. Schmidt, Y.; Simunovic, F.; Strassburg, S.; Pfeifer, D.; Stark, G.B.; Finkenzeller, G. miR-126 regulates platelet-derived growth factor receptor- $\alpha$ expression and migration of primary human osteoblasts. Biol. Chem. 2015, 396, 61-70. [CrossRef] [PubMed]

89. Goerke, S.M.; Kiefer, L.S.; Stark, G.B.; Simunovic, F.; Finkenzeller, G. miR-126 modulates angiogenic growth parameters of pe-ripheral blood endothelial progenitor cells. Biol. Chem. 2015, 396, 245-252. [CrossRef]

90. Strassburg, S.; Nabar, N.; Lampert, F.; Goerke, S.M.; Pfeifer, D.; Finkenzeller, G.; Stark, G.B.; Simunovic, F. Calmodulin Regulated Spectrin Associated Protein 1 mRNA is Directly Regulated by miR-126 in Primary Human Osteoblasts. J. Cell. Biochem. 2017, 118, 1756-1763. [CrossRef]

91. Fröhlich, L.F. MicroRNAs at the Interface between Osteogenesis and Angiogenesis as Targets for Bone Regeneration. Cells 2019, 8, 121. [CrossRef] [PubMed]

92. Schmidt, Y.; Biniossek, M.; Stark, G.B.; Finkenzeller, G.; Simunovic, F. Osteoblastic alkaline phosphatase mRNA is stabilized by binding to vimentin intermediary filaments. Biol. Chem. 2015, 396, 253-260. [CrossRef] [PubMed]

93. Hager, S.; Lampert, F.M.; Orimo, H.; Stark, G.B.; Finkenzeller, G. Up-regulation of alkaline phosphatase expression in human primary osteoblasts by cocultivation with primary endothelial cells is mediated by p38 mitogen-activated protein ki-nasedependent mRNA stabilization. Tissue Eng. Part A 2009, 15, 3437-3447. [CrossRef]

94. Rouwkema, J.; Boer, J.D.; Blitterswijk, C.A.V. Endothelial cells assemble into a 3-dimensional prevascular network in a bone tissue engineering construct. Tissue Eng. 2006, 12, 2685-2693. [CrossRef] [PubMed]

95. Goerke, S.M.; Obermeyer, J.; Plaha, J.; Stark, G.B.; Finkenzeller, G. Endothelial progenitor cells from peripheral blood support bone regeneration by provoking an angiogenic response. Microvasc. Res. 2015, 98, 40-47. [CrossRef] [PubMed]

96. Walser, R.; Metzger, W.; Görg, A.; Pohlemann, T.; Menger, M.D.; Laschke, M.W. Generation of co-culture spheroids as vascularisation units for bone tissue engineering. Eur. CellsMater. 2013, 26, 222-233.

97. Wenger, A.; Stahl, A.; Weber, H.; Finkenzeller, G.; Augustin, H.G.; Stark, G.B.; Kneser, U. Modulation of in vitro angiogenesis in a three-dimensional spheroidal coculture model for bone tissue engineering. Tissue Eng. 2004, 10, 1536-1547. [CrossRef] [PubMed] 
98. Benning, L.; Gutzweiler, L.; Tröndle, K.; Riba, J.; Zengerle, R.; Koltay, P.; Zimmermann, S.; Stark, G.B.; Finkenzeller, G. Assess-ment of hydrogels for bioprinting of endothelial cells. J. Biomed. Mater Res. A 2018, 106, 935-947. [CrossRef] [PubMed]

99. Gutzweiler, L.; Kartmann, S.; Troendle, K.; Benning, L.; Finkenzeller, G.; Zengerle, R.; Koltay, P.; Stark, G.B.; Zimmermann, S. Large scale production and controlled deposition of single HUVEC spheroids for bioprinting applications. Biofabrication 2017, 9, 025027. [CrossRef]

100. Tröndle, K.; Koch, F.; Finkenzeller, G.; Stark, G.B.; Zengerle, R.; Koltay, P.; Zimmermann, S. Bioprinting of high cell density con-structs leads to controlled lumen formation with self-assembly of endothelial cells. J. Tissue Eng. Regen Med. 2019, 10, 1883-1895. [CrossRef]

101. Rukavina, P.; Koch, F.; Wehrle, M.; Tröndle, K.; Björn Stark, G.; Koltay, P.; Zimmermann, S.; Zengerle, R.; Lampert, F.; Strassburg, S.; et al. In vivo evaluation of bioprinted pre-vascularized bone tissue. Biotechnol. Bioeng. 2020, 117, 3902-3911. [CrossRef]

102. Kang, H.-W.; Lee, S.J.; Ko, I.K.; Kengla, C.; Yoo, J.J.; Atala, A. A 3D bioprinting system to produce human-scale tissue constructs with structural integrity. Nat. Biotechnol. 2016, 34, 312-319. [CrossRef]

103. Matai, I.; Kaur, G.; Seyedsalehi, A.; McClinton, A.; Laurencin, C.T. Progress in 3D bioprinting technology for tissue/organ re-generative engineering. Biomaterials 2020, 226, 119536. [CrossRef]

104. Murphy, S.V.; Atala, A. 3D bioprinting of tissues and organs. Nat. Biotechnol. 2014, 32, 773-785. [CrossRef]

105. Malda, J.; Visser, J.; Melchels, F.P.; Jüngst, T.; Hennink, W.E.; Dhert, W.; Groll, J.; Hutmacher, D.W. 25th Anniversary Article: Engineering Hydrogels for Biofabrication. Adv. Mater. 2013, 25, 5011-5028. [CrossRef]

106. Xu, C.; Zhang, M.; Huang, Y.; Ogale, A.; Fu, J.; Markwald, R.R. Study of Droplet Formation Process during Drop-on-Demand Inkjetting of Living Cell-Laden Bioink. Langmuir 2014, 30, 9130-9138. [CrossRef]

107. Miri, A.K.; Khalilpour, A.; Cecen, B.; Maharjan, S.; Shin, S.R. Multiscale bioprinting of vascularized mod-els. Biomaterials 2019, 198, 204-216. [CrossRef] [PubMed]

108. Billiet, T.; Gevaert, E.; De Schryver, T.; Cornelissen, M.; Dubruel, P. The 3D printing of gelatin methacrylamide cell-laden tis-sue-engineered constructs with high cell viability. Biomaterials 2014, 35, 49-62. [CrossRef] [PubMed]

109. Li, B.; Wang, H.; Qiu, G.; Su, X.; Wu, Z. Synergistic Effects of Vascular Endothelial Growth Factor on Bone Morphogenetic Pro-teins Induced Bone Formation In Vivo: Influencing Factors and Future Research Directions. BioMed Res. Intl. 2016, 2869572.

110. Kreimendahl, F.; Köpf, M.; Thiebes, A.L.; Campos, D.F.D.; Blaeser, A.; Schmitz-Rode, T.; Apel, C.; Jockenhoevel, S.; Fischer, H. Three-Dimensional Printing and Angiogenesis: Tailored Agarose-Type I Collagen Blends Comprise Three-Dimensional Printability and Angiogenesis Potential for Tissue-Engineered Substitutes. Tissue Eng. Part C Methods 2017, 23, 604-615. [CrossRef] [PubMed]

111. Leucht, A.; Volz, A.-C.; Rogal, J.; Borchers, K.; Kluger, P.J. Advanced gelatin-based vascularization bioinks for extrusion-based bioprinting of vascularized bone equivalents. Sci. Rep. 2020, 10, 1-15. [CrossRef]

112. Byambaa, B.; Annabi, N.; Yue, K.; Trujillo-de Santiago, G.; Alvarez, M.M.; Jia, W.; Kazemzadeh-Narbat, M.; Shin, S.R.; Tamayol, A.; Khademhosseini, A. Bioprinted Osteogenic and Vasculogenic Patterns for Engineering 3D Bone Tissue. Adv. Healthc. Mater. 2017, 6, 1700015. [CrossRef]

113. Ning, L.; Mehta, R.; Cao, C.; Theus, A.; Tomov, M.; Zhu, N.; Weeks, E.R.; Bauser-Heaton, H.; Serpooshan, V. Embedded 3D Bi-oprinting of Gelatin Methacryloyl-Based Constructs with Highly Tunable Structural Fidelity. ACS Appl. Mater. Interfaces 2020, 12, 44563-44577. [CrossRef] [PubMed]

114. Chiesa, I.; De Maria, C.; Lapomarda, A.; Fortunato, G.M.; Montemurro, F.; Di Gesù, R.; Tuan, R.S.; Vozzi, G.; Gottardi, R. Endo-thelial cells support osteogenesis in an in vitro vascularized bone model developed by 3D bioprinting. Biofabrication 2020, 12, 025013. [CrossRef] [PubMed]

115. Abudupataer, M.; Chen, N.; Yan, S.; Alam, F.; Shi, Y.; Wang, L.; Lai, H.; Li, J.; Zhu, K.; Wang, C. Bioprinting a 3D vascular con-struct for engineering a vessel-on-a-chip. Biomed. Microdevices 2019, 22, 10. [CrossRef] [PubMed]

116. Piard, C.; Baker, H.; Kamalitdinov, T.; Fisher, J. Bioprinted osteon-like scaffolds enhance in vivo neovascularization. Biofabrication 2019, 11, 025013. [CrossRef] [PubMed]

117. Xu, L.; Varkey, M.; Jorgensen, A.; Ju, J.H.; Jin, Q.; Park, J.H.; Fu, Y.; Zhang, G.; Ke, D.; Zhao, W.; et al. Bioprinting small diameter blood vessel constructs with an endothelial and smooth muscle cell bilayer in a single step. Biofabrication 2020, $12,045012$. [CrossRef]

118. Cidonio, G.; Glinka, M.; Kim, Y.-H.; Kanczler, J.; Lanham, S.; Ahlfeld, T.; Lode, A.; Dawson, J.I.; Gelinsky, M.; Oreffo, R.O.C. Nanoclay-based 3D printed scaffolds promote vascular ingrowth ex vivo and generate bone mineral tissue in vitro and in vivo. Biofabrication 2020, 12, 035010. [CrossRef] [PubMed]

119. Kuss, M.A.; Harms, R.; Wu, S.; Wang, Y.; Untrauer, J.B.; Carlson, M.A.; Duan, B. Short-term hypoxic preconditioning promotes prevascularization in 3D bioprinted bone constructs with stromal vascular fraction derived cells. RSC Adv. 2017, 7, 29312-29320. [CrossRef]

120. Baltazar, T.; Merola, J.; Catarino, C.; Xie, C.; Kirkiles-Smith, N.C.; Lee, V.; Hotta, S.; Dai, G.; Xu, X.; Ferreira, F.C.; et al. Three Dimensional Bioprinting of a Vascularized and Perfusable Skin Graft Using Human Keratinocytes, Fibroblasts, Pericytes, and Endothelial Cells. Tissue Eng. Part A 2020, 26, 227-238. [CrossRef] [PubMed]

121. Maiullari, F.; Costantini, M.; Milan, M.; Pace, V.; Chirivì, M.; Maiullari, S.; Rainer, A.; Baci, D.; Marei, H.E.S.; Seliktar, D.; et al. A multi-cellular 3D bioprinting approach for vascularized heart tissue engineering based on HUVECs and iPSC-derived cardiomyocytes. Sci. Rep. 2018, 8, 13532. [CrossRef] [PubMed] 
122. Cui, H.; Zhu, W.; Huang, Y.; Liu, C.; Yu, Z.-X.; Nowicki, M.; Miao, S.; Cheng, Y.; Zhou, X.; Lee, S.-J.; et al. In vitro and in vivo evaluation of 3D bioprinted small-diameter vasculature with smooth muscle and endothelium. Biofabrication 2019, $12,015004$. [CrossRef] [PubMed]

123. Nulty, J.; Freeman, F.E.; Browe, D.C.; Burdis, R.; Ahern, D.P.; Pitacco, P.; Bin Lee, Y.; Alsberg, E.; Kelly, D.J. 3D bioprinting of prevascularised implants for the repair of critically-sized bone defects. Acta Biomater. 2021, 126, 154-169. [CrossRef]

124. Kérourédan, O.; Bourget, J.M.; Rémy, M.; Crauste-Manciet, S.; Kalisky, J.; Catros, S.; Thébaud, N.B.; Devillard, R. Micropattern-ing of endothelial cells to create a capillary-like network with defined architecture by laser-assisted bioprinting. J. Mater. Sci. Mater. Med. 2019, 30, 28. [CrossRef] [PubMed]

125. Kérourédan, O.; Hakobyan, D.; Rémy, M.; Ziane, S.; Dusserre, N.; Fricain, J.-C.; Delmond, S.; Thébaud, N.B.; Devillard, R. In situ prevascularization designed by laser-assisted bioprinting: Effect on bone regeneration. Biofabrication 2019, 11, 045002. [CrossRef]

126. Bourget, J.-M.; Kérourédan, O.; Medina, M.; Rémy, M.; Thébaud, N.B.; Bareille, R.; Chassande, O.; Amédée, J.; Catros, S.; Devillard, R. Patterning of Endothelial Cells and Mesenchymal Stem Cells by Laser-Assisted Bioprinting to Study Cell Migration. BioMed Res. Int. 2016, 2016, 1-7. [CrossRef]

127. Lee, V.K.; Kim, D.Y.; Ngo, H.; Lee, Y.; Seo, L.; Yoo, S.-S.; Vincent, P.A.; Dai, G. Creating perfused functional vascular channels using 3D bio-printing technology. Biomaterials 2014, 35, 8092-8102. [CrossRef]

128. Negro, A.; Cherbuin, T.; Lutolf, M.P. 3D Inkjet Printing of Complex, Cell-Laden Hydrogel Structures. Sci. Rep. 2018, 8, 1-9. [CrossRef]

129. Skylar-Scott, M.A.; Uzel, S.G.; Nam, L.L.; Ahrens, J.H.; Truby, R.L.; Damaraju, S.; Lewis, J.A. Biomanufacturing of or-gan-specific tissues with high cellular density and embedded vascular channels. Sci. Adv. 2019, 5, eaaw2459. [CrossRef]

130. Wang, Z.; Lee, S.J.; Cheng, H.-J.; Yoo, J.J.; Atala, A. 3D bioprinted functional and contractile cardiac tissue constructs. Acta Biomater. 2018, 70, 48-56. [CrossRef]

131. Tijore, A.; Behr, J.-M.; Irvine, S.A.; Baisane, V.; Venkatraman, S. Bioprinted gelatin hydrogel platform promotes smooth muscle cell contractile phenotype maintenance. Biomed. Microdevices 2018, 20, 32. [CrossRef]

132. Xu, Y.; Hu, Y.; Liu, C.; Yao, H.; Liu, B.; Mi, S. A Novel Strategy for Creating Tissue-Engineered Biomimetic Blood Vessels Using 3D Bioprinting Technology. Materials 2018, 11, 1581. [CrossRef]

133. Kolesky, D.B.; Truby, R.L.; Gladman, A.S.; Busbee, T.A.; Homan, K.A.; Lewis, J.A. Lewis, 3D bioprinting of vascularized, heterogene-ous cell-laden tissue constructs. Adv Mater 2014, 26, 3124-3130. [CrossRef] [PubMed]

134. Wu, A.P.; Whitney, M.A.; Crisp, J.L.; Friedman, B.; Tsien, R.Y.; Nguyen, Q.T. Improved facial nerve identification with novel fluorescently labeled probe. Laryngoscope 2011, 121, 805-810. [CrossRef]

135. Sawyer, S.W.; Shridhar, S.V.; Zhang, K.; Albrecht, L.D.; Filip, A.B.; Horton, J.A.; Soman, P. Perfusion directed 3D mineral for-mation within cell-laden hydrogels. Biofabrication 2018, 10, 035013. [CrossRef] [PubMed]

136. Yu, Y.; Zhang, Y.; Martin, J.; Ozbolat, I.T. Evaluation of Cell Viability and Functionality in Vessel-like Bioprintable Cell-Laden Tubular Channels. J. Biomech. Eng. 2013, 135, 091011-0910119. [CrossRef] [PubMed]

137. Bertassoni, L.E.; Cecconi, M.; Manoharan, V.; Nikkhah, M.; Hjortnaes, J.; Cristino, A.L.; Barabaschi, G.; Demarchi, D.; Dokmeci, M.R.; Yang, Y.; et al. Hydrogel bioprinted microchannel networks for vascularization of tissue engineering constructs. Lab Chip 2014, 14, 2202-2211. [CrossRef]

138. Massa, S.; Sakr, M.A.; Seo, J.; Bandaru, P.; Arneri, A.; Bersini, S.; Zare-Eelanjegh, E.; Jalilian, E.; Cha, B.-H.; Antona, S.; et al. Bioprinted 3D vascularized tissue model for drug toxicity analysis. Biomicrofluidics 2017, 11, 044109. [CrossRef]

139. Miller, J.; Stevens, K.R.; Yang, M.T.; Baker, B.; Nguyen, D.-H.T.; Cohen, D.; Toro, E.; Chen, A.A.; Galie, P.A.; Yu, X.; et al. Rapid casting of patterned vascular networks for perfusable engineered three-dimensional tissues. Nat. Mater. 2012, 11, 768-774. [CrossRef]

140. Eltaher, H.M.; Abukunna, F.E.; Ruiz-Cantu, L.; Stone, Z.; Yang, J.; Dixon, J.E. Human-scale tissues with patterned vascular networks by additive manufacturing of sacrificial sugar-protein composites. Acta Biomater. 2020, 113, 339-349. [CrossRef]

141. Thomas, A.; Orellano, I.; Lam, T.; Noichl, B.; Geiger, M.-A.; Amler, A.-K.; Kreuder, A.-E.; Palmer, C.; Duda, G.; Lauster, R.; et al. Vascular bioprinting with enzymatically degradable bioinks via multi-material projection-based stereolithography. Acta Biomater. 2020, 117, 121-132. [CrossRef] [PubMed]

142. Lee, V.K.; Lanzi, A.M.; Ngo, H.; Yoo, S.-S.; Vincent, P.A.; Dai, G. Generation of Multi-scale Vascular Network System Within 3D Hydrogel Using 3D Bio-printing Technology. Cell. Mol. Bioeng. 2014, 7, 460-472. [CrossRef]

143. Kneser, U.; Schaefer, D.J.; Polykandriotis, E.; Horch, R.E. Tissue engineering of bone: The reconstructive surgeon's point of view. J. Cell. Mol. Med. 2006, 10, 7-19. [CrossRef] [PubMed]

144. Auger, F.A.; Gibot, L.; Lacroix, D. The Pivotal Role of Vascularization in Tissue Engineering. Annu. Rev. Biomed. Eng. 2013, 15, 177-200. [CrossRef] [PubMed]

145. Scheufler, O.; Schaefer, D.J.; Jaquiéry, C.; Braccini, A.; Wendt, D.J.; Gasser, J.A.; Galli, R.; Pierer, G.; Heberer, M.; Martin, I. Spatial and temporal patterns of bone formation in ectopically pre-fabricated, autologous cell-based engineered bone flaps in rabbits. $J$. Cell. Mol. Med. 2008, 12, 1238-1249. [CrossRef] [PubMed]

146. Kneser, U.; Stangenberg, L.; Ohnolz, J.; Buettner, O.; Stern-Straeter, J.; Möbest, D.; Horch, R.E.; Stark, G.B.; Schaefer, D.J. Evaluation of processed bovine cancellous bone matrix seeded with syngenic osteoblasts in a critical size calvarial defect rat model. J. Cell. Mol. Med. 2006, 10, 695-707. [CrossRef] 
147. Akar, B.; Tatara, A.M.; Sutradhar, A.; Hsiao, H.-Y.; Miller, M.; Cheng, M.-H.; Mikos, A.G.; Brey, E.M. Large Animal Models of an In Vivo Bioreactor for Engineering Vascularized Bone. Tissue Eng. Part B Rev. 2018, 24, 317-325. [CrossRef]

148. Arkudas, A.; Lipp, A.; Buehrer, G.; Arnold, I.; Dafinova, D.; Brandl, A.; Beier, J.P.; Körner, C.; Lyer, S.; Alexiou, C.; et al. Pedicled Transplantation of Axially Vascularized Bone Constructs in a Critical Size Femoral Defect. Tissue Eng. Part A 2018, 24, 479-492. [CrossRef]

149. Warnke, P.; Springer, I.; Wiltfang, J.; Acil, Y.; Eufinger, H.; Wehmöller, M.; Russo, P.; Bolte, H.; Sherry, E.; Behrens, E.; et al. Growth and transplantation of a custom vascularised bone graft in a man. Lancet 2004, 364, 766-770. [CrossRef]

150. Weigand, A.; Horch, R.E.; Boos, A.M.; Beier, J.P.; Arkudas, A. The Arteriovenous Loop: Engineering of Axially Vascularized Tissue. Eur. Surg. Res. 2018, 59, 286-299. [CrossRef]

151. Arkudas, A.; Beier, J.P.; Heidner, K.; Tjiawi, J.; Polykandriotis, E.; Srour, S.; Sturzl, M.; Horch, R.E.; Kneser, U. Axial prevascularization of porous matrices using an arteriovenous loop promotes survival and differentiation of transplanted autologous os-teoblasts. Tissue Eng. 2007, 13, 1549-1560.

152. Arkudas, A.; Beier, J.P.; Pryymachuk, G.; Hoereth, T.; Bleiziffer, O.; Polykandriotis, E.; Hess, A.; Gulle, H.; Horch, R.E.; Kneser, U. Automatic Quantitative Micro-Computed Tomography Evaluation of Angiogenesis in an Axially Vascularized Tissue-Engineered Bone Construct. Tissue Eng. Part C Methods 2010, 16, 1503-1514. [CrossRef]

153. Beier, J.P.; Horch, R.E.; Hess, A.; Arkudas, A.; Heinrich, J.; Loew, J.; Gulle, H.; Polykandriotis, E.; Bleiziffer, O.; Kneser, U. Axial vascularization of a large volume calcium phosphate ceramic bone substitute in the sheep AV loop model. J. Tissue Eng. Regen. Med. 2009, 4, 216-223. [CrossRef] [PubMed]

154. Horch, R.E.; Beier, J.P.; Kneser, U.; Arkudas, A. Successful human long-term application of in situ bone tissue engineering. J. Cell. Mol. Med. 2014, 18, 1478-1485. [CrossRef] [PubMed]

155. Mian, R.; Morrison, W.A.; Hurley, J.V.; Penington, A.; Romeo, R.; Tanaka, Y.; Knight, K.R. Formation of New Tissue from an Arteriovenous Loop in the Absence of Added Extracellular Matrix. Tissue Eng. 2000, 6, 595-603. [CrossRef] [PubMed]

156. Leibig, N.; Wietbrock, J.O.; Bigdeli, A.K.; Horch, R.E.; Kremer, T.; Kneser, U.; Schmidt, V.J. Flow-Induced Axial Vascularization: The Arteriovenous Loop in Angiogenesis and Tissue Engineering. Plast Reconstr. Surg. 2016, 138, 825-835. [CrossRef]

157. Matsuda, K.; Falkenberg, K.J.; Woods, A.A.; Choi, Y.S.; Morrison, W.A.; Dilley, R.J. Adipose-derived stem cells promote angiogenesis and tissue formation for in vivo tissue engineering. Tissue Eng. Part A 2013, 19, 1327-1335. [CrossRef]

158. Bhumiratana, S.; Bernhard, J.C.; Alfi, D.M.; Yeager, K.; Eton, R.E.; Bova, J.; Shah, F.; Gimble, J.M.; Lopez, M.; Eisig, S.B.; et al. Tissue-engineered autologous grafts for facial bone reconstruction. Sci. Transl. Med. 2016, 8, 343ra83. [CrossRef] [PubMed] 